\title{
AGGREGATE PRODUCTION FUNCTION AND INCOME IDENTITY- EMPIRICAL ANALYSIS
}

\author{
JAN CADIL, KRISTYNA VLTAVSKA , IGOR KREJČÍ, DAVID HARTMAN, MAREK \\ $B R A B E C$
}

\begin{abstract}
:
Aggregate production function, especially in its Cobb-Douglas and more general CES form, is still very popular among economists. However there is a huge and long-standing critique regarding the function. The core of the criticism which prevailed until these days is that not only the Cobb-Douglas but also CES aggregate production functions are nothing more than income identity in disguise. Such fact would have serious implications for contemporary macroeconomics - both theory and practice. In this paper we estimated Cobb-Douglas and CES production functions in traditional way. Then we used capital and labour services instead of capital stock and labour. We came to conclusion that to get statistically sound results when elasticities equal factor shares, it is necessary to use the latter approach to deal with the factor's utilization. However doing so revealed that such modified estimate is really only an estimate of income identity in disguise as predicted by the critique.
\end{abstract}

\section{Keywords:}

Aggregate production function, Income identity, Capital services, Labour services

JEL Classification: O00, E23, E25

\section{Authors:}

JAN CADIL, Unicorn College and University of Economics, Prague, Czech Republic, Email: jan.cadil@unicorncollege.cz

KRISTYNA VLTAVSKA, University of Economics, Prague and Czech Statistical Office, Czech Republic, Email:

IGOR KREJČí, University of Life Sciences, Prague, Czech Republic, Email:

DAVID HARTMAN, Unicorn College and Institute of Computer Science, Czech Academy ofSciences, Czech Republic, Email:

MAREK BRABEC, Institute of Computer Science, Czech Academy ofSciences, Czech Republic, Email:

\section{Citation:}

JAN CADIL, KRISTYNA VLTAVSKA, IGOR KREJČÍ, DAVID HARTMAN, MAREK BRABEC (2017). AGGREGATE PRODUCTION FUNCTION AND INCOME IDENTITY- EMPIRICAL ANALYSIS. International Journal of Economic Sciences, Vol. VI(1), pp. 1-17., 10.20472/ES.2017.6.1.001 


\section{Introduction}

Aggregate production function namely Cobb-Douglas production function (CDPF) and its upgrades like transcendental logarithmic (translog) or constant elasticity of substitution (CES) functions are still widely used and also discussed by various institutions and researchers. Estimation of aggregate production function has many purposes - from potential output gap estimation to growth accounting and total factor productivity (TFP) estimation. The ability to explain the aggregate output creation and economic growth on relatively simple basis is naturally still very attractive. However, the aggregate production function, especially in its simple Cobb-Douglas form, is continuously being criticized and tested for various reasons.

Generally, we may identify two areas of problems when dealing with aggregate production function. The first one is theoretical and can be labelled as truly critical. The second area is empirical and is not that much about critique but more about an observed gap between the aggregate production function assumptions (and estimates) and reality. Of course, these two areas often intersect usually giving feeding ground to each other.

When we take a brief look into the history of production function we may see it quite clearly. The first estimate and the introduction of the function by Cobb and Douglas $(1928)^{1}$ was instantly under heavy critique from various points of view - from econometrical to economic theory - as Douglas himself remembers (Douglas 1967). One of the first critiques was made by Mendershausen $(1938,1939)$ who criticized what the function really measures labelling the function as "confluent relation". However, the Cobb-Douglas function prevailed, on the contrary it has become very popular in time. Robert Solow uses Cobb-Douglas aggregate production function as a basis for his pioneering growth model (Solow 1956) and subsequent growth accounting formula (Solow 1957) which is widely used even today, more than 50 years later. On the other hand, Kaldor (1957) empirically proved that capital to output ratio is roughly constant in time which meant that economies should be in steady states according to Solow's model (which was hard to believe). Abramowitz (1956: 11) addressed the aggregate production function residual - the TFP - and labelled it as a "measure of our ignorance". Moreover Brown (1957) proposed that Cobb-Douglas production is just an ex post applied accounting relation. Consequently, Simon and Levy (1963) very simply showed that the coefficients in CDPF function are easily obtained from income identity and that CDPF function is nothing more than a transformation of income identity. This finding is then readdressed several times - for example by Samuleson (1979) or Shaikh (1974). On the contrary in 1960's the production function evolves - new functions, namely CES and translog function, as upgrades to CDPF appear. Moreover, Arrow (1962) and Uzawa (1965) laid basis of new (endogenous) growth theory which was greatly improved by Romer (1986) and Lucas (1988). The main driving force was

\footnotetext{
${ }^{1}$ Although the function is named after Cobb and Douglas it appeared probably for the first time in the work of von Thünen in late 1840s (Humphrey 1997).
} 
to deal with problems the CDPF brings especially from the empirical point of view (constant capital to output ratio, proof of non-convergence). Despite these changes, the critique did not disappear. Simon (1979) concluded that neither CDFP nor CES function can be regarded as production functions but they should rather be viewed as "simply the accounting relation equating value of output to the sum of factor costs". Later Felipe and Adams (2005) and Felipe and McCombie $(2001,2005)$ came to the same conclusion - that CDPF but also CES are not production functions in neoclassical sense, but just an income identity transformation. One would expect such heavy arguments will cause a withdrawal from aggregate production function. But what happened was quite the opposite. Since 1990's CDPF and CES alike are becoming more and more popular among economist. Besides standard statistical estimates, the so called index approach also becomes popular ${ }^{2}$. On top of that aggregate production function becomes being used for estimation of potential output by various institutions like ministries of finance or central banks. Also the growth accounting and index approach (in various "modern" forms) are repeatedly used for TFP estimates and explanations of sources of growth.

From the empirical point of view estimation of Cobb-Douglas aggregate production function is facing various complications, especially with data that are being used. Besides that, some "strange" estimation results are sometimes presented as well. From the data point of view we have to deal with only two inputs when using standard CDPF or CES - capital and labour. In 1950's crucial critique of capital in production function comes from post-Keynesians, namely Robinson (1953) and started quite famous "Cambridge capital controversy" debate. Robinson claimed that as we may aggregate capital only in terms of its values, we cannot separate it from distribution and prices. In other words when we aggregate capital we must use its money values because otherwise it is impossible. However, these values are partly determined by the rate of profit which is supposed in neoclassical view being dependent on the amount of capital that is used in production. This circularity in neoclassical theory was never sufficiently explained and has been damaging the aggregate production function theory till these days.

Besides this theoretical critique of capital in production function, other more practical problems occurred. Historically real capital stock was used and the main problem was to calculate the stock using usually the perpetual inventory method (PIM). However, such approach seems inappropriate today as it does not reflect the actual capital utilization. So called capital services seem to be a more eligible input as the utilization can be expressed only in terms of profits. To give a short example, an idle factory does not produce anything, thus generating no profit. It is therefore (correctly) not present in

\footnotetext{
${ }^{2}$ Robert Solow (1957) was the first author who showed that under certain circumstances the Divisia index is the natural way of indexing technical change (Hulten 1973). Index approach is usually used for short run analysis. It captures only the first and the last value in the time series. It is regarded a useful tool for the competitiveness analysis (see index approach recommendation, OECD 2001).
} 
capital services but is (incorrectly) calculated towards capital stock ${ }^{3}$. It is definitely more appropriate and more in line with the critique above to use the capital services instead of capital stock. In practice capital services are usually defined as profits plus mixed income

(Sixta,

Fischer

2009).

For the labour input the situation is very similar. Historically number of employees was used, but according to European System of Accounts (ESA 1995) the hours worked should be added instead. Moreover we could, as in the case of capital, address the utilization rate of labour. Again if we assume that more utilized labour is better paid and use the labour services instead of the labour itself. These are equal to total labour cost.

The "strange results" mentioned above address the fact that quite often estimates of Cobb-Douglas production function brought negative sign of capital (see Romer 1987, Girliches and Mairesse 1998). Also Felipe and Adams (2005) gained such results even for the original Cobb-Douglas data from 1928 when adding a time trend for technological progress. A question arises why the aggregate production function, despite its huge empirical and theoretical drawbacks, is still so popular.

Surprisingly, in spite of various theoretical articles and critical experiments mentioned above, there is a very limited number of empirical studies dealing with the aggregate production function and its link to accounting identity. The purpose of this paper is therefore to empirically test the Cobb-Douglas and CES aggregate production function and to show empirically that it is rather an income identity in disguise than production function in the neoclassical sense. We focus on standard estimation of CDPF and CES using the capital stock, and then we use capital services and labour services as well. We compare these possible empirical approaches and make recommendations from the empirical point of view. We use data for the Czech Republic as all data needed for such estimation are available now.

\section{Standard production function estimates}

Firstly, we review the Cobb-Douglas function and its standard econometric estimation to highlight the problems such methodology produces. This function in its original form exhibits constant returns to scale $(\alpha+\beta=1)$ when elasticities of production on production factors should equal factor shares. They are supposed to be lower than 1 and higher than 0 . Decreasing returns from particular factors satisfy Inada conditions. The original function states

$Y_{t}=A_{t}\left(K_{t}\right)^{\alpha}\left(L_{t}\right)^{\beta}$

\footnotetext{
${ }^{3}$ This example helps us to distinguish the capital evaluation by the purpose of analysis, which is the point of view we suppose to be stressed. Capital services are appropriate for production function analysis. On the contrary, when the analysis is focused on potential production (e.g. Giorno et al. 1995), the capital stock is the correct input. In case of potential production, the goal is to find what could be produced with all available factors. Likewise using potential employment, the idle factory is a part of potentially useful capital.
} 
where $K$ stands for capital, $L$ for labour and $A$ is the Total factor productivity . Putting (1) in logarithms, which is the standard approach to linearize (1), we estimate the first model from Table 1 below $^{4}$. Note that TFP has two components: long-term component and variable component, which is the estimation residual ${ }^{5}$. Hours worked, capital stock, and gross value added; both in constant 2005 prices, were used in the time series 1996-2011, quarterly data. The database of the Czech Statistical Office was used. Nevertheless, quarterly fixed capital stocks are not officially published. Such a situation is common for most statistical offices. Kamps (2006) notes that most researchers use a quarterly flow indicator of gross fixed capital formation instead of capital stock for econometric analysis (vector autoregressive models for public capital productivity analysis in Kamps' comment). Such an indicator (which is inflow for the capital stock) is only one part of yearly change of the stock. Thus, it is inappropriate for production function analysis. Therefore, we proposed a method that uses the same data as official perpetual inventory method but it uses all possible information to divide three basic flows (gross fixed capital formation, consumption of fixed capital and other changes in the volume of assets) into quarters to calculate quarterly development of net stock indicator. For full description of this approach and quarterly stock estimates see Krejčí and VItavská (2013). All series were seasonally adjusted by Tramo Seats.

The standard approach is to test for stationarity of time series and cointegration prior to the regression. However, Felipe and Adams (2005) correctly indicate that it is meaningless as we estimate identity in fact. This is explained in the following section. Moreover, we also test dynamic models where stationarity can be expected.

Applying the OLS on log-linearized (1) yields results that are not that satisfying. Consult Table 1, $\rho$ values in parentheses. Low DW statistics indicate autocorrelation in residuals; residuals are not normally distributed according to Jarque-Berra test. Elasticities definitely do not match the factor shares especially in the case of capital. Moreover, it seems that despite low correlation coefficient between independent variables, there is a strong collinearity present ${ }^{6}$ according to Variance Inflation Factors (VIF) test (see Appendix). Such collinearity could potentially restrict the estimation leading to possible high variance of coefficients (low t-tests), implausible magnitude or sign of coefficients. In other words, the production function estimate possibly does not yield true information about the contributions of inputs to output. However, it should be stressed that contemporary approach of researchers in the field of production function is to accept the multicollinearity among independent variables, despite the well-known

\footnotetext{
${ }^{4}$ It is quite common to use an index form or a growth form of the function using factor shares directly and not estimate them econometrically. However it is our intention to show that econometrical approach yields very different results. The average factor shares are 0.46 for labour and 0.54 for capital for period 1996-2011. This is in line with domestic studies. For example Hájek and Bezděk (2000) used labour share of 0.48 and 0.52 for capital, Hájek (2008) arrives to similar values but his approach to TFP estimate is criticized for using employed population instead of hours worked (Fischer and Sixta, 2009).

${ }^{5}$ It means that $\ln \left(A_{t}\right)=b_{0}+\varepsilon_{t}$ where $\varepsilon_{t}$ is the residual.

${ }^{6}$ Although the correlation coefficient of capital and labour is around 0.3 it is, by far, not proof of the absence of collinearity (Belsley 1991). It is because correlation is linear co-variability of two variables around their means, but collinearity refers to the presence of linear dependencies between two raw, uncentered variables (Silvey 1969).
} 
fact that it hinders interpretability of the estimated coefficients. Multicollinearity is regarded as typical characteristics of Cobb-Douglas functions estimates. Having the correlation coefficient much lower than the $\mathrm{R}^{2}$ of all estimates and t-statistics of independent variables being high, then multicollinearity should not affect the validity of estimates (Kennedy 2003). This is the case of the estimates presented in this paper. On the other hand, the results here must be corrected as they are clearly unrealistic. There are several ways how to deal with collinearity. The easiest way is getting rid of one of the variables but it would destroy the whole model (and production theory itself) and therefore it is not appropriate. Other possibility is to modify the model and add some other independent variables. This will be addressed in the following section. Kamps (2004) suggests to use panel data approach (either countries or industries) to deal with multicollinearity. Although this might be helpful, this paper deals with national aggregated data and this option is left for further research. However, the usual modification to deal with collinearity is to adjust the model for per capita terms when we assume constant returns to scale in production function. It is also convenient to allow for an exponential time trend of technical progress (so called Tinbergen-Solow equation). The modification of (1) in per capita terms with time trend is

$\frac{Y_{t}}{L_{t}}=A_{t} e^{\sigma t}\left(\frac{K_{t}}{L_{t}}\right)^{\alpha}$

where $e^{\sigma t}$ represents assumed exponential growth of technology over time. The total TFP then consists of long term constant, time dependent growth trend and short term fluctuations expressed by residuals. As Table 1 shows, modification (2) brings surprising result mentioned in the introduction - negative sign for capital to labour ratio. Besides the negative sign for capital, residuals are still correlated despite the time trend. As can be seen from the correlogram of residuals (see Appendix) there is a strong correlation at lag 1 . In this case it is usual to adopt the autoregressive (AR1) process, where $\varepsilon_{t}=\rho \varepsilon_{t-1}+\mu_{t}$. Doing this yields better results regarding the serial correlation in residuals but the overall model is not satisfying - the capital per hour worked variable is negative again.

The next possible step for gaining better results is to make first difference transformation of production function. This standard transformation probably solves the possible non-stationarity problem and under assumption of very small changes in variables we get the Solow's growth accounting equation (Solow 1957) as ${ }^{7}$

$$
d \ln \left(Y_{t}\right)=d \ln \left(A_{t}\right)+\alpha d \ln \left(K_{t}\right)+\beta d \ln \left(L_{t}\right) \quad,
$$

\footnotetext{
${ }^{7}$ As generally growth rates can be approximated by difference in logarithms $d \ln (y)=\frac{d y}{y}$ we get well known growth accounting as $\frac{d Y}{Y}=\frac{d A}{A}+\alpha \frac{d K}{K}+\beta \frac{d L}{L}$.
} 
where differences in logarithms approximately equal growth rates and estimated parameter bo stands for the TFP long-term growth rate (trend). Although the growth of capital and labour is not collinear this time as VIF test shows (as contain Appendix) ${ }^{8}$ estimating the growth accounting (3) using OLS however does not bring any better results. Capital is again negative and insignificant, residuals are serially correlated. As correlogram shows the residuals are again correlated at lag 1 so AR (1) process should be employed again. Doing so brings results that are not acceptable either. Although the residuals are not correlated this time, growth of capital is again negative and insignificant.

Obviously estimating standard quarterly Cobb-Douglas production function for the case of the Czech Republic is quite problematic. It is of course possible to move to more general form of production function - to CES function when we possibly might expect different results. The advantage of CES function is that it allows for non-unitary elasticity of substitution between factors. On the other hand, we should stress that it is still a two factor production function, just a general case of Cobb-Douglas, with all related critical issues mentioned above. The standard CES function with constant returns to scale originating from Arrow et al. (1961) has the form

$$
\left(Y_{t}\right)=A_{t}\left(\alpha\left(K_{t}\right)^{-\rho}+(1-\alpha)\left(L_{t}\right)^{-\rho}\right)^{-\left(\frac{1}{\rho}\right)} \quad,
$$

when $\rho$ represents the degree of substitutability between production factors. For $\rho=0$ we get standard Cobb-Douglas production function with unitary elasticity of substitution. The CES function is estimated by MLE (Maximum likelihood estimation) with starting values of $\alpha=0.54$ and $\rho=1$. Using the Henningsen and Henningsen (2013) package in R, R-core (2013), we fitted CES with both additive (normal) errors and and multiplicative (lognormal) errors. Fit of the additive model is a bit better, but both estimates fit the data poorly. Although R2 is 0.75 , the RMSE is 55302.98 and 56199.93 , bias 3851.30 and -6106.32 for additive and multiplicative models, respectively. Estimated parameters of both additive and multiplicative models are rather extreme and unrealistic, since their values are right on the boundary of the parameter space. For both cases we get the estimate of $\alpha=1, \rho=1.546$ and $b 0=-2.98$. We explored much wider choice of the initial values with convergence to essentially the same point or divergence. Looking at the parameter estimates, it is clear that from the CES viewpoint, the data tend to favor a much simpler model than the full CES indeed! This pathological behavior is not surprising when we look at how badly the CES function (4) fits the data - as seen from the large RMSE and biases and diagnostic plots (not shown here). Restricting the $\rho=0$ yields the same (bad) estimates as CDPF estimate [1] in Table 1 because CES is simplified to CDPF.

\footnotetext{
8 This indicates that the multicollinearity is really most likely not the true problem of the production function estimation as discussed above.
} 
Table 1: Cobb-Douglas and CES production functions estimates

\begin{tabular}{|c|c|c|c|c|c|c|}
\hline Estimated models & bo & $t$ & $K_{t}$ & $L_{t}$ & $\mathrm{R} 2$ & DW \\
\hline [1] $\ln \left(Y_{t}\right)=b_{0}+b_{1} \ln \left(K_{t}\right)+b_{2} \ln \left(L_{t}\right)+\varepsilon_{t}$ & $\begin{array}{l}-23.03^{* * *} \\
(0.000)\end{array}$ & & $\begin{array}{l}1.78^{* * *} \\
(0.000)\end{array}$ & $\begin{array}{l}0.49^{* * *} \\
(0.002)\end{array}$ & $\begin{array}{l}0.9 \\
1\end{array}$ & $\begin{array}{l}0.1 \\
0\end{array}$ \\
\hline$[2 \mathrm{~A}] \ln \left(\frac{Y_{t}}{L_{t}}\right)=b_{0}+\sigma t+b_{1} \ln \left(\frac{K_{t}}{L_{t}}\right)+\varepsilon_{t}$ & $\begin{array}{l}14.21^{* * *} \\
(0.000)\end{array}$ & $\begin{array}{l}0.01^{* * *} \\
(0.000)\end{array}$ & $\begin{array}{l}-0.6^{* * *} \\
(0.000)\end{array}$ & & $\begin{array}{l}0.9 \\
6\end{array}$ & $\begin{array}{l}0.1 \\
0\end{array}$ \\
\hline $\begin{array}{c}\ln \left(\frac{Y_{t}}{L_{t}}\right)=b_{0}+\sigma t+b_{1} \ln \left(\frac{K_{t}}{L_{t}}\right)+\varepsilon_{t} \\
\varepsilon_{t}=\rho \varepsilon_{t-1}+\mu_{t}\end{array}$ & $\begin{array}{l}13.75^{\star * \star} \\
(0.000)\end{array}$ & $\begin{array}{l}0.01^{* * *} \\
(0.000)\end{array}$ & $\begin{array}{l}-0.36^{* * *} \\
(0.002)\end{array}$ & & $\begin{array}{l}0.9 \\
9\end{array}$ & 1.0 \\
\hline$[3 \mathrm{~A}] d \ln \left(Y_{t}\right)=b_{0}+b_{1} d \ln \left(K_{t}\right)+b_{2} d \ln \left(L_{t}\right)+\varepsilon_{t}$ & $\begin{array}{l}0.008^{\star * *} \\
(0.000)\end{array}$ & & $\begin{array}{l}-0.10 \\
(0.584)\end{array}$ & $\begin{array}{l}0.48^{* * *} \\
(0.000)\end{array}$ & $\begin{array}{l}0.2 \\
2\end{array}$ & $\begin{array}{l}1.0 \\
4\end{array}$ \\
\hline $\begin{array}{c}\text { [3B] } d \ln \left(Y_{t}\right)=b_{0}+b_{1} d \ln \left(K_{t}\right)+b_{2} d \ln \left(L_{t}\right)+\varepsilon_{t} \\
\varepsilon_{t}=\rho \varepsilon_{t-1}+\mu_{t}\end{array}$ & $\begin{array}{l}0.007^{* *} \\
(0.02)\end{array}$ & & $\begin{array}{l}-0.06 \\
(0.63)\end{array}$ & $\begin{array}{l}0.36^{* * *} \\
(0.000)\end{array}$ & $\begin{array}{l}0.4 \\
1\end{array}$ & 2.1 \\
\hline
\end{tabular}

${ }^{*}$ denotes $90 \%$ significance, ${ }^{* \star} 95 \%$ significance, ${ }^{* \star *} 99 \%$ significance

To conclude this section we may say that the standard production function estimates for Czech Republic on quarterly aggregated data simply do not work. Estimates are not consistent with production theory - elasticity of output to capital is either unrealistic or usually negative which is on the other hand conclusion obtained by many similar studies. Moreover the estimated elasticities are absolutely not equal not even close to factor shares as predicted by Euler's theorem for the case of CDPF. Therefore we should discuss the production function itself - not only its specification and variables but especially the overall meaning of the function. Although the standard CobbDouglas production or CES might seem to work for other economies the case of the Czech Republic is (among others) the reason why to look for the revision of standard approach to production estimates and to deal with the critical insights highlighted in the introduction.

\section{Production function and accounting identity}

Cobb-Douglas production function suffers from several theoretical but also practical drawbacks that were many times mentioned by various researchers before and summarized in the introduction of this article. These problems might empirically lead to incorrect or misleading estimates as was demonstrated in previous section on Czech data. Therefore it is necessary to think of revision in standard approach to production function modelling - empirically and theoretically as well.

Firstly, let us take a look at the data. As mentioned above it is probably more correct to substitute the capital stock with capital services as they reflect the utilization of capital. The same is probably true for the labour services. Such approach was deeply studied by OECD (Ahmad 2004, Schreyer 2007) and also used in contemporary practice (see Timmer, O'Mahony and van Ark, 2007 for example). Capital services can be expressed as return to capital (net operating surplus plus mixed income) and consumption of fixed capital (Sixta and Fischer 2009) but they should also equal profit rate times capital stock. We may also, with a high degree of precision, calculate the 
capital services from the income identity. It shows how the income (value added) is distributed between capital and labour. We calculate capital services simply like ${ }^{9}$

$r_{t} K_{t}=Y_{t}-w_{t} L_{t}$

where $w$ denotes a labour cost rate and $r$ represents the profit rate (both in real terms). In other words total income is equal to capital services plus labour services. For the case of Czech Republic the difference between capital services calculated from (5) and the profits plus mixed income is really negligible, the average deviation is $1,6 \%$ while the maximum deviation is $4 \%$ - see Figure $1^{10}$.

\section{Figure 1: Capital services - calculation and differences}

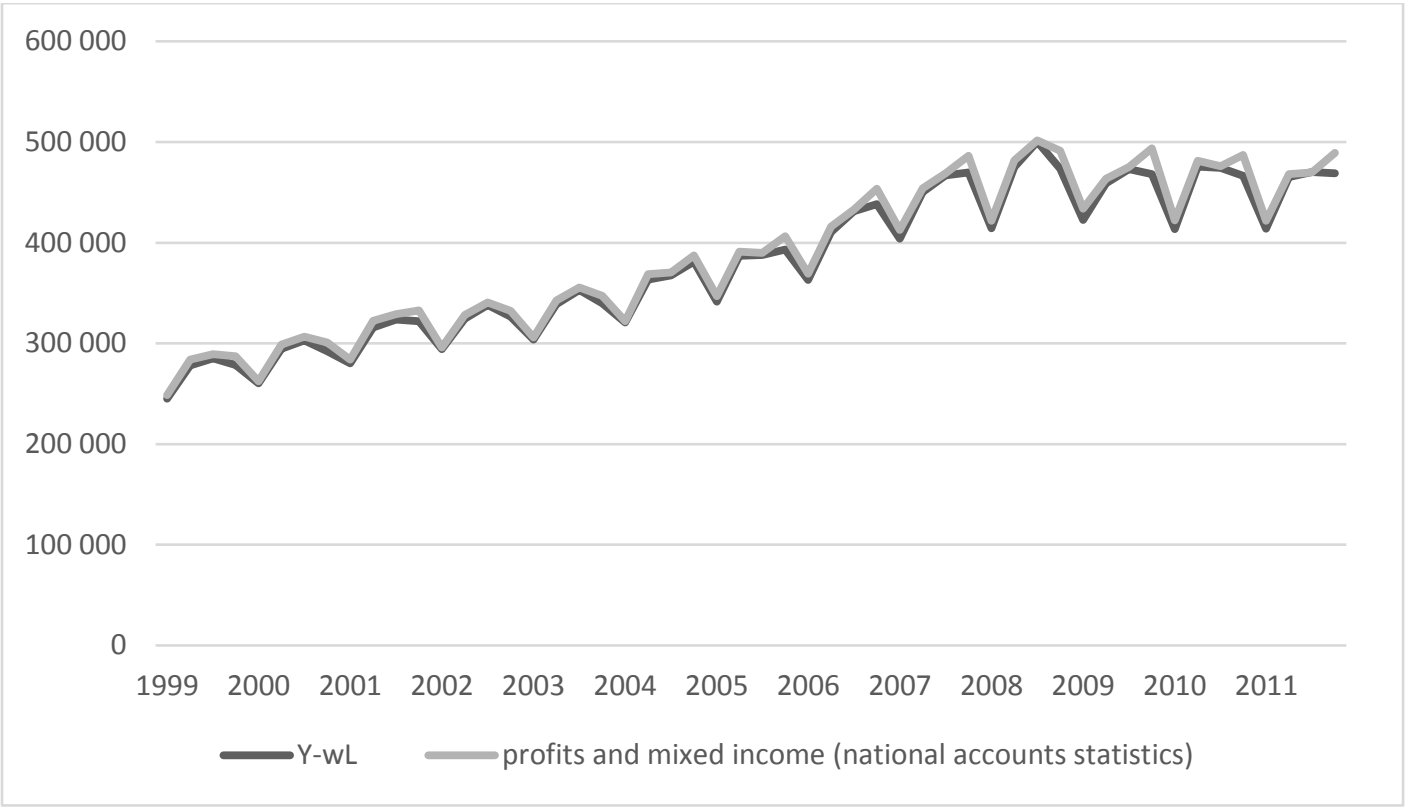

Source: Czech Statistical Office, own calculation

Adjusting standard CDPF (1) by substituting capital services for capital and labour services for labour yields

$Y_{t}=A_{t}(r K)_{t}^{\alpha}(w L)_{t}^{\beta}$

Equation (6) differs from (1) especially in terms of $A_{t}$ which is now reduced by employing factor payments. It is quite interesting that (6) can also be obtained from the accounting identity itself as Felipe and Adams (2005) suggests. If we start with (5) and make first differences we get

\footnotetext{
${ }^{9}$ Samuleson (1979) uses this approach in his Strategic counterexample labeling it as „profit returns to property“.

10 Data about profits and mixed income were available only for the time series 1999-2011. We may however consider it sufficient to conclude that the variables are roughly equal.
} 
$\frac{d Y_{t}}{Y_{t}}=\left(\frac{(r K)_{t}}{Y_{t}}\right)\left(\frac{d K_{t}}{K_{t}}\right)+\left(\frac{(r K)_{t}}{Y_{t}}\right)\left(\frac{d r_{t}}{r_{t}}\right)+\left(\frac{(w L)_{t}}{Y_{t}}\right)\left(\frac{d L_{t}}{L_{t}}\right)+\left(\frac{(w L)_{t}}{Y_{t}}\right)\left(\frac{d w_{t}}{w_{t}}\right)$

When we assume the factor shares to be constant in time and label the factor shares as $\alpha=\frac{(r K)_{t}}{Y_{t}}$ and $\beta=\frac{(w L)_{t}}{Y_{t}}$ then after integration of (7) we get

$Y_{t}=B(r K)_{t}^{\alpha}(w L)_{t}^{\beta} \quad$,

where $B$ represents integration constant. It is quite clear that equations (6) and (8) are very similar, even the same if we allow the "technology" $A$ to follow the standard process when there is a long term constant and changing residuals (see footnote 2 ). In other words, if we make logarithmic linearization of (6) or (8) we estimate the same model

$$
\ln \left(Y_{t}\right)=b_{0}+b_{1} \ln (r K)_{t}+b_{2} \ln (w L)_{t}+\varepsilon_{t}
$$

It is quite clear that using proper inputs as capital services and labour services in CobbDouglas production function yields the same functional form as we get from accounting identity. The TFP (residual plus constant) now mainly reflects the assumption of constant factor shares which allowed us to connect income identity with CDPF. If we compare the TFP of (6) and (8) to that of (1) it is clear, that it would differ especially because of factor payments which embody the factor's utilization rate. Estimation of (9) yields very promising results - in its static but also dynamic version of our "pseudo" growth accounting.

Table 2: Estimates of CDPF with capital and labour services

\begin{tabular}{|c|c|c|c|c|c|}
\hline Estimated models & bo & $(r K)_{t}$ & $(w L)_{t}$ & $\mathrm{R} 2$ & DW \\
\hline$[9 \mathrm{~A}] \ln \left(Y_{t}\right)=b_{0}+b_{1} \ln (r K)_{t}+b_{2} \ln (w L)_{t}+\varepsilon_{t}$ & $\begin{array}{l}0.7^{* * *} \\
(0.000)\end{array}$ & $\begin{array}{l}0.54^{* * *} \\
(0.000)\end{array}$ & $\begin{array}{l}0.46^{* \star *} \\
(0.000)\end{array}$ & $\begin{array}{l}0.9 \\
9\end{array}$ & $\begin{array}{l}0.5 \\
2\end{array}$ \\
\hline $\begin{array}{c}\text { [9B] } \ln \left(Y_{t}\right)=b_{0}+b_{1} \ln (r K)_{t}+b_{2} \ln (w L)_{t}+\varepsilon_{t} \\
\varepsilon_{t}=\rho \varepsilon_{t-1}+\mu_{t}\end{array}$ & $\begin{array}{l}0.7^{* * *} \\
(0.000)\end{array}$ & $\begin{array}{l}0.54^{* \star \star} \\
(0.000)\end{array}$ & $\begin{array}{l}0.46^{\star \star \star} \\
(0.000)\end{array}$ & $\begin{array}{l}0.9 \\
9\end{array}$ & $\begin{array}{l}2.2 \\
4\end{array}$ \\
\hline $\begin{array}{l}{[9 \mathrm{C}] d \ln \left(Y_{t}\right)=b_{0}+b_{1} d \ln (r K)_{t}+} \\
b_{2} d \ln (w L)_{t}+\varepsilon_{t}\end{array}$ & $\begin{array}{l}0.0004 \\
(0.983)\end{array}$ & $\begin{array}{l}0.54^{\star \star \star} \\
(0.000)\end{array}$ & $\begin{array}{l}0.46^{* * *} \\
(0.000)\end{array}$ & $\begin{array}{l}0.9 \\
9\end{array}$ & $\begin{array}{l}2.3 \\
9\end{array}$ \\
\hline
\end{tabular}

*denotes $90 \%$ significance, ${ }^{* *} 95 \%$ significance, ${ }^{* *} 99 \%$ significance

We can see that when we estimate static (9) it yields very good results. The only problem is possible autocorrelation of residuals but adding $A R(1)$ solves this flaw. The results of model [9B] are statistically correct (regarding the residuals), the fit is very high and estimates almost perfectly equal average factor shares for the 1996-2011 period. Moreover we can see that also the assumption of constant returns to scale is perfectly fulfilled. For the dynamic version the constant term is statistically insignificant while elasticities remain the same as in static version. Again the factor shares again equal elasticities, we have constant returns to scale. Additionally we got rid of the growth of the constant term which would mean that the residual was reduced significantly and our model works even better from the sources of growth explanation 
point of view. For the CES estimate with same starting values as before we get very good results this time too. R2 is reaching 1 as in the case of CDPF estimates. Setting initial $\rho=1$ we get for the additive model the estimate of $\alpha=0.5, \rho=-1$ and $b 0=0.69$. RMSE is $9.63 e-10$, bias $9.31 e-10$. For the multiplicative model and the same initial values we get the estimate of $\alpha=0.55, \rho=0.25$ and $b 0=0.69$. RMSE is then 165.20 and bias 3.26 (fit of the multiplicative model is worse, similarly as before, in section 2). When restricting $\rho=0$ we get the same results as for $[9 \mathrm{~A}]$.

Although we should normally be happy that we finally have a proper Cobb-Douglas production function (and CES) estimates, it would not be appropriate. As shown above these "good" results are only a result of tautology which was put forward by Samuleson (1979) and others long time ago. We prove that it is necessary to deal with capital and labour services to get sound estimates. However doing so transforms the CobbDouglas aggregate production function into modification of accounting identity. This is the truth for the Cobb-Douglas function (and CES function) generally - the only difference is the quality of estimate. When the services, i.e. factor payments or some rate of utilization, are not included it may hamper the estimate and/or manifest itself in high TFP. Out of our empirical results we are deeply convinced that CDPF is really a transformation of income identity and probably cannot be claimed as a neoclassical aggregate production function.

\section{Conclusion}

Aggregate production function, namely in its Cobb-Douglas or CES form, is still widely used among economists. Moreover its popularity grows from 1990's especially in connection with increased popularity of "new growth" models. Today we find dozens of various applications utilizing CDPF (in various modifications including index approaches) focusing usually on TFP estimates, convergence, business cycle and potential output. In spite of its popularity the CDPF suffers from several serious drawbacks. There is a long-standing critique of CDPF based especially on the convention that the function itself is not a production function in neoclassical sense but just a transformation of aggregate income identity. If this is the truth we should ask: What new does the aggregate production bring? The answer is, according to our opinion, nothing. Nothing besides a blurred picture of sources of growth and very mysterious residual called TFP, which however mainly represents correction for factors utilization, i.e. factor payments. In our article we tried to compare the aggregate production estimates for the Czech Republic and find out if there is an empirical reason to support the CDPF critique. When standard methodology was used with capital stock for capital and hours worked for labour the results were not convincing. For the standard CDPF estimates the coefficients (elasticities) were far away from the factor shares. When we added the time trend, which is quite standard modification, the capital became negative. Although this might seem as a surprising result it is quite common and even the original CDPF from 1928 would yield such a result. The dynamic form, which is the Solow's famous growth accounting in fact, did not bring any better results - the capital was again negative and insignificant. When we tried to use a more 
sophisticated aggregate function - CES function - we got similarly bad results. To conclude we could not statistically reach a reasonable aggregate production function for the Czech Republic on quarterly basis with common functional forms and methods. We decided to use capital services and labour services which are more reasonable especially from the factor utilization point of view. Such approach is in line with contemporary recommendations to production function empirical estimates. However when we put capital and factor services into CDPF we found out that this is truly just a transformation of income identity. Although our approach was mainly based on putting correct data into Cobb-Douglas function, we came to the same conclusion as many critiques of the CDPF. When we estimated such modified function we got very nice results. Estimated elasticities equal factor shares as assumed and the function clearly exhibits constant returns to scale. Unfortunately, this outcome is not because we used proper data and the CDPF worked at last but just because we estimated the income identity in disguise. On empirical basis we have to confirm the conclusions made theoretically by Samuelson (1979) and others that the Cobb-Douglas aggregate production function is most likely nothing more than income identity and economists should be aware of it. 


\section{Appendix}

Table 3: Variance Inflation Factors for estimate [1]

\begin{tabular}{|c|c|c|c|}
\hline \multicolumn{4}{|c|}{ Variance Inflation Factors } \\
\hline \multicolumn{4}{|c|}{ Date: $01 / 24 / 14$ Time: $10: 53$} \\
\hline \multicolumn{4}{|c|}{ Variance Inflation Factors } \\
\hline \multicolumn{4}{|c|}{ Date: 01/24/14 Time: 11:07 } \\
\hline \multicolumn{4}{|c|}{ Sample: 1996Q1 2011Q4 } \\
\hline \multicolumn{4}{|c|}{ Included observations: 64} \\
\hline & Coefficient & Uncentered & Centered \\
\hline Variable & Variance & VIF & VIF \\
\hline LOG(K_SA) & 0.006110 & 41576.40 & 1.333855 \\
\hline LOG(L_SA) & 0.026157 & 137486.9 & 1.333855 \\
\hline C & 10.06412 & 254710.0 & NA \\
\hline
\end{tabular}

Table 4: Correlogram, estimate [2A]

\begin{tabular}{|c|c|c|c|c|c|c|}
\hline Autocorrelation & Partial Correlation & & $A C$ & PAC & Q-Stat & Prob \\
\hline$\cdot||^{\star \star \star \star \star *} \mid$ & $\cdot||^{\star \star \star \star \star \star} \mid$ & 1 & 0.896 & 0.896 & 53.797 & 0.000 \\
\hline$\cdot||^{\star \star * \star \star *} \mid$ & $.{ }^{*} . \quad \mid$ & 2 & 0.778 & -0.125 & 94.997 & 0.000 \\
\hline$\left.\cdot\right|^{* \star \star \star *} \mid$ & $.^{*} . \quad \mid$ & 3 & 0.658 & -0.070 & 124.98 & 0.000 \\
\hline$.||^{\star \star \star \star} \mid$ & .1 .1 & 4 & 0.544 & -0.042 & 145.82 & 0.000 \\
\hline$.\left.\right|^{* * \star} \mid$ & $.{ }^{*} . \quad \mid$ & 5 & 0.420 & -0.128 & 158.47 & 0.000 \\
\hline$.\left.\right|^{* *} \mid$ & $.{ }^{*} . \quad \mid$ & 6 & 0.291 & -0.111 & 164.64 & 0.000 \\
\hline$.\left.\right|^{*} . \quad \mid$ & .1 .1 & 7 & 0.177 & -0.016 & 166.96 & 0.000 \\
\hline .1 .1 &.${ }^{*}$. & 8 & 0.067 & -0.088 & 167.30 & 0.000 \\
\hline
\end{tabular}




\section{Table 5: Variance Inflation Factors for estimate [3A]}

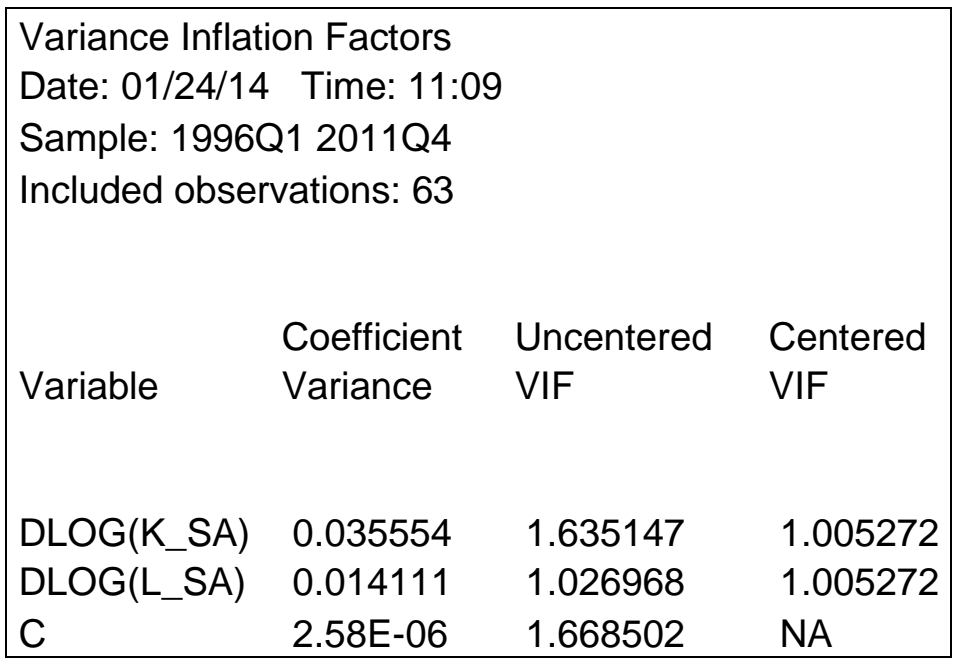

Table 6: Correlogram, estimate [2A]

\begin{tabular}{|c|c|c|c|c|c|}
\hline Autocorrelation & Partial Correlation & $A C$ & PAC & Q-Stat & Prob \\
\hline$.\left.\right|^{\star \star \star} \mid$ & $.\left.\right|^{* * *} \mid$ & $\begin{array}{ll}1 & 0.461\end{array}$ & 0.461 & 14.021 & 0.000 \\
\hline$.\left.\right|^{* \star *} \mid$ & $.\left.\right|^{*} . \mid$ & 20.353 & 0.179 & 22.408 & 0.000 \\
\hline$.\left.\right|^{* *} \mid$ &.$||$. & $\begin{array}{ll}3 & 0.246\end{array}$ & 0.039 & 26.532 & 0.000 \\
\hline.$||$. & $. * \mid$ & $\begin{array}{ll}40.035 \\
\end{array}$ & -0.174 & 26.617 & 0.000 \\
\hline .1 .1 & .1 .1 & $\begin{array}{ll}50.056\end{array}$ & 0.053 & 26.837 & 0.000 \\
\hline.$||$. &.$||$. & $\begin{array}{ll}6 & 0.032\end{array}$ & 0.035 & 26.912 & 0.000 \\
\hline .1 .1 & $.\left.\right|^{*} . \quad \mid$ & 70.070 & 0.086 & 27.271 & 0.000 \\
\hline .1 .1 & $.{ }^{*} \mid$ & $\begin{array}{ll}8 & 0.012\end{array}$ & -0.089 & 27.282 & 0.001 \\
\hline
\end{tabular}

\section{References}

Abramovitz M (1956) Resource and Output Trends in the U.S. since 1870. American Economic Review 46: $5-23$

Ahmad N (2004) Introducing Capital Services into the Production Account - Update. Paper presented to the meeting of the Canberra Group in Washington

Arrow KJ, Chenery HB, Minhas BS, Solow RM (1961) Capital-Labor Substitution and Economic Efficiency. The Review of Economics and Statistics 43/3: 225-250

Arrow KJ (1962) The Economic Implications of Learning by Doing. The Review of Economic Studies 29: 155-123. doi: $10.2307 / 2295952$

Belsley DA (1991) Conditioning Diagnostics: Collinearity and Weak Data in Regression. Wiley, New York 
Brown EHP (1957) The Meaning of the Fitted Cobb-Douglas Production Function.

The Quarterly Journal of Economics 71: 546-560. doi: 10.2307/1885710

Cobb CW, Douglas PH (1928) A Theory of Production. American Economic Review 18: 139-65

Czech Statistical Office (2013), Quarterly National Accounts.

http://www.czso.cz/eng/redakce.nsf/i/hdp_ts

Douglas PH (1967) Comments on the Cobb-Douglas Production Function. In: Brown M (ed) The Theory and Empirical Analysis of Production. National Bureau of Economic Research, Cambridge, MA, pp 15-22

Felipe J, Adams FG (2005) "A Theory of Production" The Estimation of the Cobb-Douglas Function: A Retrospective View. Eastern Economics Journal 31: 427-446

Felipe J, McCombie JSL (2001) The CES Production Function, The Accounting Identity and Occam's Razor. Applied Economics 33: 1221-1232

Felipe J, McCombie JSL (2005) How Sound are the Foundations of the Aggregate Production Function? Eastern EconomicJournal 31: 467-488

Fischer J, Sixta J (2009) K propočtu souhrnné produktivity faktorů. Politická ekonomie 57: 544-554

Giorno C, Richardson P, Roseveare D, van den Noord P, (1995) Potential Output, Output Gaps and Structural Budget Balances. OECD Journal: Economic Studies, 24: 167-209

Griliches Z, Mairesse J (1998) Production Functions: The Search for Identification. In: Strøm S (ed) Econometrics and Economic Theory in the 20th Century.Cambridge University Press, Cambridge, pp 169-203

Hájek M, Bezděk V (2000) Odhad potenciálního produktu a produkční mezery v ČR [Estimation of potential production and production gap in CR]. Czech National Bank, Prague.

Hájek M (2008) Ekonomický růst v České republice a nových členských zemích Evropské unie v období 1995-2006. Politická ekonomie 56: 435-448

Henningsen A, Henningsen G (2011). Econometric Estimation of the" Constant Elasticity of Substitution" Function in R: Package micEconCES. Institute of Food and Resource Economics, University of Copenhagen

Hulten Ch R (1973) Divisia Index Numbers. Econometrica 41: 1017-1025

Humphrey TM (1997) Algebraic Production Functions and Their Uses Before Cobb-Douglas. FRB Richmond Economic Quarterly 83: 51-83

Kaldor N (1957): A model of economic growth. The Economic Journal 67: 591-624

Kamps C (2006) New Estimates of Government Net Capital Stocks for 22 OECD Countries, 1960-2001, IMF Staff Papers 53: 120-150

Kamps C (2004) The Dynamic Macroeconomic Effects of Public Capital: Theory and Evidence for OECD Countries, Springer 
Kennedy P (2003) A Guide to Econometrics. MIT Press, Cambridge, MA.

Krejči I, VItavská K (2013) Measuring Quarterly Net Fixed Capital Stock in the Czech Republic. Acta univ. agric. et silvic. Mendel. Brunen, 61: 2367-2376. doi: 10.11118/actaun201361072367

Lucas RE (1988) On the Mechanics of Economic Development. Journalof Monetary Economics 22: 342. doi: 10.1016/0304-3932(88)90168-7

Mendershausen H (1938) On the Significance of Professor Douglas' Production Function.

Econometrica 6: 143-153

Mendershausen H (1939) On the Significance of Professor Douglas' Production Function: A Correction. Econometrica 7: 362

OECD (2001) Measuring Productivity. OECD Web.

http://www.oecd.org/std/productivity-stats/2352458.pdf. Accessed 20 January 2014

R-core (2013): R software, http://cran.at.r-project.org/

Robinson J (1953) The Production Function and the Theory of Capital. Review of

Economic Studies 21: 81-106. doi: 10.2307/2296002

Romer P (1986) Increasing Returns and Long Run Growth. Journal of Political Economy 94: 1002-1037. doi: $10.1086 / 261420$

Romer P (1987) Crazy Explanations for the Productivity Slowdown. In: Fischer S (ed) The NBER Macroeconomics Annual 1987. National Bureau of Economic Research, Cambridge, MA, pp 163202

Samuelson P (1979) Paul Douglas's Measurement of Production Functions and Marginal Productivities. Journal of Political Economy 87: 923-39. doi: 10.1086/260806

Schreyer P (2007), Measuring Capital. A paper presented at the Paris meeting of the Working Party on National Accounts, OECD

Shaikh A (1974) Laws of Production and Laws of Algebra: The Humbug Production

Function. Review of Economics and Statistics 56: 115-120

Silvey SD (1969) Multicollinearity and Imprecise Estimation. Journal of the Royal Statistical Society. Series B (Methodological) 31: 539-52

Simon H, Levy F (1963) A Note on the Cobb-Douglas Function. Review of Economic Studies 30: 93-94. doi:10.2307/2295806

Simon H (1979) On Parsimonious Explanations of Production Relations. The

Scandinavian Journal of Economics 81: 459-474. doi: 10.2307/3439661

Sixta J, Fischer, J (2009) Capital services and supply and tables compilation. In: 17th International InputOutput Conference. USP, Sao Paulo 
Solow R (1956) A Contribution to the Theory of Economic Growth. The Quarterly Journal of Economics 70: 65-94. doi: 10.2307/1884513

Solow R (1957) Technical Change and the Aggregate Production Function. Review of Economics and Statistics 39: 312-320

Timmer M. P., O'Mahony M., van Ark B. (2007) EU KLEMS Growth and Productivity Accounts: Overview November 2007 Release. EU KLEMS Web.

http://www.euklems.net/project_site.html. Accessed 2 January 2014

Uzawa H (1965) Optimum Technical Change in An Aggregative Model of Economic Growth. International Economic Review 6: 18-31. 